\section{Pediatric Endocrinology Diabetes and Metabolism}

In memoriam | Wspomnienie

Pediatr Endocrinol Diabetes Metab 2019; 25 (2): 53 DOI: https://doi.org/10.5114/pedm.2019.86050 www.pteidd.pl

\title{
Dr hab. n. med. Maria Kalina (1975-2019)
}

19 marca br. odeszła od nas nasza Koleżanka Maja Kalina. Przez wiele miesięcy zmagała się heroicznie z ciężką chorobą, prawie do ostatnich dni współpracując z nami w diagnozowaniu i leczeniu „swoich” pacjentów z rzadkimi i skomplikowanymi zaburzeniami genetycznymi.

Pracowała w Klinice Pediatrii i Endokrynologii Dziecięcej Śląskiego Uniwersytetu Medycznego od 2001 r., przechodząc kolejne etapy awansu naukowego i zdobywając specjalizacje z pediatrii, endokrynologii i diabetologii dziecięcej oraz z genetyki klinicznej. Wszystkie Jej dokonania były zawsze na najwyższym poziomie, poczynając od międzynarodowej matury w United World College of the Atlantic w Wielkiej Brytanii, dyplomu ukończenia studiów

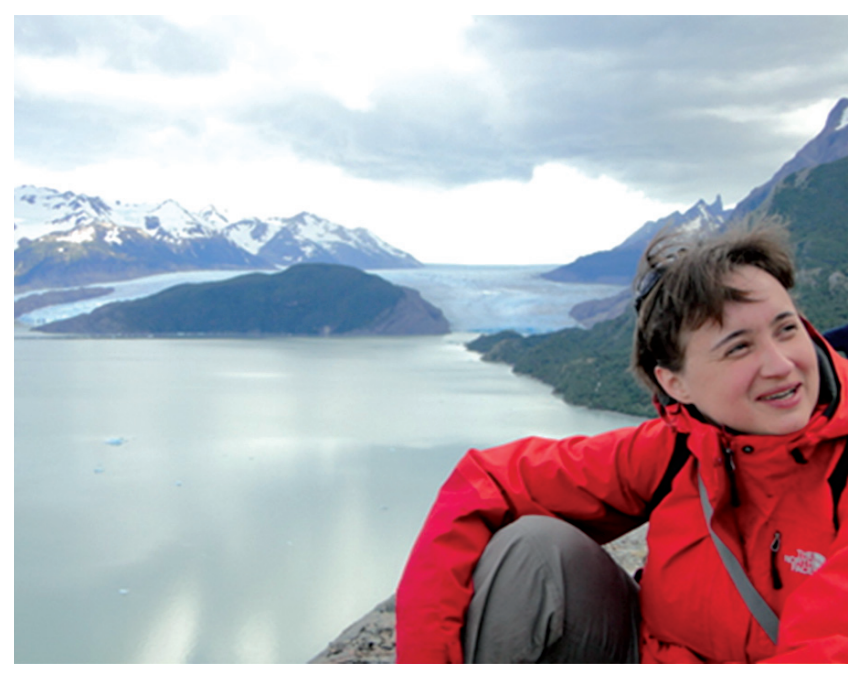
lekarskich z najwyższą lokatą na roku, uzyskania stypendium ESPE na staż kliniczny w Edynburgu oraz wykładów na wielu międzynarodowych kursach i szkoleniach.

Miała ogromną wiedzę i doświadczenie kliniczne. Wykorzystywała je w pracy z pacjentami oraz na zajęciach ze studentami Wydziału Lekarskiego, których potrafiła zarażać swoją pasją. Swoją imponującą wiedzą dzieliła się z całym zespołem Kliniki, otaczając opieką rezydentów i pomagając młodszym koleżankom w pracy naukowej. Opublikowała szereg prac naukowych, uzyskując w 2016 r. stopień doktora habilitowanego.

Maja kochała swoją pracę i kochała życie. Miała przyjaciół na całym świecie i utrzymywała z nimi regularne kontakty, często dzieląc się z nami opowieściami ze swoich podróży i spotkań. Miała też wiele planów na przyszłość. Rok wcześniej podjęła decyzję o objęciu funkcji kierownika Zakładu Genetyki Klinicznej Katedry Biologii Molekularnej i Genetyki.

We wszystkich swoich działaniach mogła zawsze liczyć na starszą siostrę Basię, która była dla Niej po śmieci rodziców najbliższą osobą. Pracując w tej samej dziedzinie, stworzyły obie niezwykle zgrany zespół wspólnie podejmujący trudne decyzje kliniczne. Basia była obecna w życiu Mai „w zdrowiu i w chorobie”, czuwając przy niej każdego dnia, do ostatniej chwili nie tracąc nadziei, że będzie lepiej.

Kochana Maju, bardzo nam Ciebie brakuje i nie możemy pogodzić się z Twoim odejściem. Będziesz zawsze obecna w naszych wspomnieniach i w naszych sercach. Śpij spokojnie.

Ewa Małecka-Tendera wraz z zespołem pracowników 